\title{
Assessment of Breeding Potential of Cherry Tomato [Solanum lycopersicum var. Cerasiforme (Dunnal) A. Gray] Grown under Open Field to Identify Desirable Alleles
}

\author{
Debmala Mukherjee ${ }^{1}$, Praveen Kumar Maurya ${ }^{1}$, Tridip Bhattacharjee ${ }^{1}$, \\ Swadesh Banerjee ${ }^{1}$, Subhrajyoti Chatterjee ${ }^{1}$, Sudipa Mal ${ }^{2}$, Ivi Chakraborty ${ }^{3}$, \\ Soumitra Chatterjee ${ }^{4}$, Sunanda Chakraborty ${ }^{5}$, Anirban Maji ${ }^{6}$ and \\ Arup Chattopadhyay ${ }^{1 *}$
}

${ }^{1}$ Department of Vegetable Science, ${ }^{2}$ Department of Agricultural Chemistry and Soil Science, ${ }^{3}$ Department of Post-Harvest Technology, ${ }^{4}$ Department of Agricultural Economics, ${ }^{5}$ Department of Plant Pathology, ${ }^{6}$ Department of Genetics and Plant Breeding, Faculty of Agriculture, Bidhan Chandra Krishi Viswavidyalaya, Mohanpur-741252, Nadia, West Bengal, India

*Corresponding author

\section{A B S T R A C T}

\section{Keywords \\ Cherry tomato, Multivariate analysis, Selection index, ToLCV disease}

\section{Article Info}

Accepted:

18 March 2020

Available Online:

10 April 2020
Assessment of advance breeding lines of cherry tomato for reproductive, fruit quality and disease severity attributes could provide insight into the underlying biology of the source of desirable alleles for breeding for open field production. The study was undertaken to evaluate 14 newly developed breeding lines from India to utilize useful genes in cherry tomato breeding, and to assess genetic variability and character associationship among 19 quantitative characters to identify important selection indices, and genetic divergence to identify potential donor(s) for breeding cherry tomato especially under open field condition. Genotypes Cherry Round Yellow and 16/ToCVAR-1 appeared the most promising and could commercially be exploited as open field varieties in tropical and sub-tropical regions of the world, after critical testing. High, genotypic coefficient of variation, heritability coupled with genetic advance, occurred for pericarp thickness, fruit firmness, ascorbic acid content, titratable acidity content, total antioxidant activity of fruit, percent disease index of tomato leaf curl virus (PDI of ToLCV), and fruit yield per plant, which suggests that the characters concerned are conditioned by additive gene action and therefore, these characters would be more reliable for effective selection. The top priority should be given to selection based on fruit per flower cluster, pericarp thickness, fruit firmness, number of flower clusters per plant, fruit weight, and retinal activity equivalent for yield improvement and could be considered while formulating selection indices in the improvement of cherry tomato for open field condition. Geographical diversity was not adequate as an index of genetic diversity in field grown cherry tomatoes. The principal components, titratable acidity content, fruit yield per plant, PDI of ToLCV, and total antioxidant acidity, had eigen values $>1$ and together accounted for $100 \%$ of total variation. Based on multivariate analysis and average values, genotypes 16/ToCVAR-1, 16/ToCVAR-3, 16/ToCVAR-4, 16/ToCVAR-5, 16/ToCVAR6, and Cherry Round Yellow were identified as potential donors that could be passed on to breeders not only for ToLCV resistant breeding but also for improvement in yield and better nutritional quality of cherry tomato either through development of hybrids, or isolation of potential lines from segregating generations, suitable for open field culture in tropical and subtropical regions of the world. 


\section{Introduction}

In tropical and sub-tropical parts of the world cultivation of cherry tomatoes [Solanum lycopersicum var. cerasiforme (Dunnal) A. Gray] is limited, sporadically grown under protected culture, and requires further investigation for their suitability under open field condition. Crop is widely cultivated in Central America and distributed in the US, Korea, Germany, and Mexico (Gharezi et al., 2012). The crop is adapted in warmer regions, requires long growing seasons, and is successful under protected structures (Vidyadhar et al., 2014).

There has been a decrease in greenhouse cherry tomato area and harvest as a result of structural and commercial problems (Testa et al., 2014). There is the possibility of growing cherry tomatoes under open field conditions, particularly in tropical and sub-tropical regions of the world (Mukherjee et al., 2019), if proper care is taken towards managing tomato leaf curl virus (TolCV) disease. Open field grown crops can create opportunities for small and marginal growers, who can diversify production and increase sales.

The collection and conservation of plant genetic resources without being accompanied by information about agronomic characteristics, and genetic potential makes collections in simple deposits of material without utility.

Genetic diversity in cherry tomato across the world exhibits wide variability for yield component traits and fruit quality characteristics flavor, aroma, color, texture and high antioxidant vitamins and bioactive compounds (Miller and Tanksley, 1990; Nuez, 1999; Medina and Lobo, 2001; Kobryn and Hallmann, 2005; Stommel et al., 2005; Lenucci et al., 2006; Rosales et al., 2011; Renuka et al., 2014; Ramya et al., 2016;
Venkadeswaran et al., 2018; Mukherjee, 2019) indicating great potential for improving this type of tomato, or for introgressing genes for materials with large fruit. Current breeding efforts in cherry tomato focus on incorporating such fruit qualities into new commercial cultivars. Evaluation of advance breeding lines for desired horticultural characteristics to identify superior cherry tomato genotypes for additional improvement in yield, fruit quality and disease tolerance traits is necessary.

Quantification of genetic divergence through biometrical procedures has made it possible to choose genetically diverse parents for successful hybridization. The utility of multivariate analysis for measuring the degree of genetic divergence and for assessing relative contributions of different yield contributing and fruit quality characters to total divergence in cherry tomato has been established (Garzón, 2011; Aguirre and Cabrera, 2012). Little information on selection of cherry tomato genotypes based on genetic divergence in relation to field tolerance against ToLCV disease necessitates further study. It is necessary to improve existing cultivars, or develop new hybrid combinations, for high yield, nutritional qualities with appreciable leaf curl disease tolerance, better consumer acceptability, and to meet consumer demand across tropical and sub-tropical regions of the world.

The study was undertaken to determine genetic variability parameters for reproductive and fruit quality characters and leaf curl disease severity influencing yield, their interrelationships, and to assess genetic diversity among 14 cherry tomato genotypes grown under open field condition to explore the possibility of utilizing desirable alleles in future breeding for tropical and sun-tropical regions of the world. 


\section{Materials and Methods}

\section{Plant materials and field growing}

Field experiments were conducted during autumn-winter seasons (September 2018 to February 2019) at the research plot of All India Coordinated Research Project on Vegetable Crops, Bidhan Chandra Krishi Viswavidyalaya, Kalyani, Nadia, West Bengal, India, at $23.5^{\circ} \mathrm{N}$ latitude and $89^{\circ} \mathrm{E}$ longitude at a mean sea level of $9.75 \mathrm{~m}$.

Fourteen advanced breeding lines collected from locations in India (Indian Institute of Vegetable Research, Varanasi, UP and Bidhan Chanfra Krishi Viswavidyalaya, West Bengal) were used. The sandy loam soil was solarized with transparent polymulch, $100 \mu \mathrm{m}$ thickness, for 4 weeks. Beds $20 \mathrm{~cm}$ tall and $1.0 \mathrm{~m}$ wide were constructed. Weathered cow manure at $2.5 \mathrm{~kg} \cdot \mathrm{m}^{-2}$ was mixed into the soil. Beds were drenched with chlorothalonil $(0.2 \%)+$ carbendazim $(0.01 \%)$ to avoid damping off disease. Seed of genotypes were sown manually in lines spaced at 5-7 cm distance in nursery beds. Nursery beds were covered with $200 \mu \mathrm{m}$ ultraviolet (UV)stabilized polyethylene film supported by bamboo poles with open sides to protect seedlings from rain and direct sunlight. After sowing, seed beds were covered with straw until germination which normally takes 5 to 7 days and were hand watered daily to maintain soil moisture. Seedlings were hardened by withholding water 4 days before transplanting.

The soil, neutral in reaction ( $\mathrm{pH}$ 6.9), low in organic carbon $\left(4.2 \mathrm{~g} \cdot \mathrm{kg}^{-1}\right)$ and available $\mathrm{N}$ $\left(138 \mathrm{~kg} \cdot \mathrm{ha}^{-1}\right)$, high in available $\mathrm{P}\left(47 \mathrm{~kg} \cdot \mathrm{ha}^{-1}\right)$ and medium in available $\mathrm{K}$ contents (130 $\mathrm{kg} \cdot \mathrm{ha}^{-1}$ ) was ploughed and brought to fine tilth. Cow manure @ $5 \mathrm{Mt}^{-1} \mathrm{ha}^{-1}$ and 120N:60P:60K $\mathrm{kg} \cdot \mathrm{ha}^{-1}$ was applied (Mukherjee et al., 2019). Half of $\mathrm{N}$ and all the
$\mathrm{P}$ and $\mathrm{K}$ were applied at soil preparation and the other half of $\mathrm{N}$ top dressed twice at 30 and 50 days after transplanting (DAT). Thirty-day old seedlings of genotypes were transplanted separately in $3.0 \times 3.0 \mathrm{~m}$ plots spaced $50 \mathrm{~cm}$ both ways in a randomized complete block design with 3 replications. Vines were staked with bamboo sticks and jute rope to support the indeterminate growth habit. Two main branches were retained just below the first flower to ensure strong plant architecture. The crop was maintained according to Malik et al., (2017).

\section{Data recording}

Data were recorded from 15 randomly selected plants of each replication on days to $50 \%$ flowering, number of flower clusters per plant, number of fruit per flower cluster, fruit weight, polar diameter, equatorial diameter, number of locules per fruit, pericarp thickness, fruit firmness by fruit penetrometer, and fruit yield per plant. Fruit of all genotypes were harvested at ripe stage. Twenty randomly selected fruit of different trusses from each genotype were brought to the laboratory of Post-Harvest Technology of Horticultural Crops.

Total soluble solids (TSS) of clear juice samples were determined by digital Refractometer (model PR-32 $\alpha$, ATAGO, Tokyo, Japan) and the result expressed in ${ }^{\circ}$ Brix after temperature correction. Titratable acidity was estimated by titrating $5 \mathrm{~mL}$ of sample against $0.1 \mathrm{~N} \mathrm{NaOH}$ solution using phenolphthalein as an indicator. The acidity was calculated and expressed as percent anhydrous citric acid according to established procedures (Anonymous, 1990). Ascorbic acid content was estimated by titration with 2,6-dichlorophenolindophenol sodium salt solution according to established procedures (Anonymous, 1990), lycopene and $\beta$-carotene contents were determined spectrophoto- 
metrically (Davies, 1976). Retinal equivalent activity (RAE) of fruit was estimated with accepted formulae (Anonymous, 2006). Total antioxidant activity was estimated by $1,1-$ diphenyl-2-picrylhydrazyl (DPPH) radical scavenging assay with a spectrophotometer at $517 \mathrm{~nm}$ (Braca et al., 2001).

Percent Disease Index (PDI) was estimated using a disease severity scale (0-4) described by Banerjee and Kalloo (1987) at 120 DAT with the formula of McKinney and Davis (1925). A 4-step scale was used for evaluation of resistant/susceptible reaction of genotypes based on PDI (Cao et al., 2009) as follows: a) highly tolerant (HT) $\mathrm{PDI} \leq 15 \%$; b) moderately tolerant (MT) $16 \%<\mathrm{PDI} \leq 25 \%$; c) moderately susceptible (MS) $26 \%<\mathrm{PDI} \leq 45 \%$, and d) highly susceptible (HS) PDI $>45 \%$.

\section{Data analysis}

Data were subjected to analysis of variance for a randomized complete block design (Gomez and Gomez, 1984). Genotypic means were separated using Least Significant Differences following Tukey's post hoc test. The genotypic co-efficient of variation (GCV) and phenotypic co-efficient of variation (PCV) were calculated by the formula of Burton (1952). For estimates of heritability (broad sense) and genetic advance, as percent of mean, the method of Hanson et al., (1956) was followed.

Correlation coefficients at genotypic and phenotypic levels were calculated (Johnson et al., 1955). Path coefficient analysis was per Dewey and $\mathrm{Lu}$ (1959). The $\mathrm{D}^{2}$ statistic (Mahalanobis, 1936) was used to assess genetic divergence of genotypes. Grouping populations was by Tocher's method (Rao, 1952). Hierarchical cluster analysis was done to determine degree of association according to their characteristics and a dendrogram constructed following Ward's (1963) method. Principal component analysis, was used to identify the factor dimension of the data, to summarize varietal information in a reduced number of factors (titratable acidity content, fruit yield per plant, PDI of ToLCV, and total antioxidant acidity) for selection of best performing genotype(s). All analyses were computed using INDOSTAT (ver. 8.1, Indostat services, Ameerpet, Hyderabad, India).

\section{Results and Discussion}

\section{Mean performance of genotypes}

Genotype affected most traits except number of locules per fruit and fruit $\beta$-carotene content (Table 1). The co-efficient of variation $(\mathrm{CV})$ was $<10 \%$ for days to $50 \%$ flowering, polar diameter, equatorial diameter, pericarp thickness, fruit firmness, TSS content, ascorbic acid content, titratable acidity content, $\beta$-carotene content, retinol activity equivalent and total antioxidant activity, indicating, although not studied, lessened genotype by environment interactions. The $\mathrm{CV}$ values for other characters indicated the possibility of moderate genotype by environment interactions.

Responses of quantitative characters varied (Table 2, 3). Minimum days to 50\% flowering were in 17/ToCVAR-5, followed by 16/ToCVAR-2; the most days was in 17/ToCVAR-1. Numbers of flower clusters produced was highest in Cherry Round Yellow; the least was in Cherry Round Red Big Fruit. The most fruit produced in a cluster was in Cherry Round Yellow and the least in Cherry Round Red Big Fruit. The heaviest fruit was in Cherry Round Red Big Fruit and the lightest was in Cherry Round Yellow. Genotype Cherry Round Red Big Fruit had the greatest polar diameter followed by 16/ToCVAR-5. The greatest equatorial diameter was in Cherry Round Red Big Fruit and the least in Cherry Round Yellow. The 
most fruit per plant was for Cherry Round Yellow followed by 16/ToCVAR-3, and the fewest were for Cherry Round Red Big Fruit. Little variation in locule number occurred among genotypes. The thickest pericarp was in Cherry Round Red Big Fruit. The firmest fruit was for 16/ToCVAR-5 followed by 16/ToCVAR-1. The greatest fruit yield per plant was for Cherry Round Yellow and 16/ToCVAR-1. Four genotypes produced $>2.00 \mathrm{~kg}$ of fruit per plant.

The maximum TSS content was for Cherry Round Red Big Fruit followed by 16/ToCVAR-6. Twelve of 14 genotypes exhibited more than $5.0{ }^{\circ}$ Brix, suitable for fresh market and processing. The most ascorbic acid was in Cherry Round Red followed by $17 /$ ToCVAR-6. The most acid fruit was in 17/ToCVAR-6. The most lycopene was in $17 /$ ToCVAR-4. The most $\beta$ carotene was in Cherry Round Red. The maximum retinal activity equivalent was in Cherry Round Red. The most total antioxidant activity was in 16/ToCVAR-1 and Cherry Round Yellow. Disease severity among genotypes varied at 120DAT under field condition (Table 3). Genotypes 16/ToCVAR1, Cherry Round Yellow, 16/ToCVAR-4 and 16/ToCVAR-3 had <10\% PDI values, and categorized as resistant.

Small and marginal farmers, predominant in tropical and sub-tropical countries, cannot afford high cost of protected culture and grow cherry tomatoes under open field condition. Evaluation of cherry tomato genotypes under open field condition is necessary to judge their potential, open marketing opportunities, and create a source of income to small holder growers. All genotypes affected in flowering time were late flowering, with a few early flowering genotypes (Venkadeswaran et al., 2018). Flowering may be a genetic character or an effect of environment. Maximum number of productive flower clusters per plant, and high retention of fruit in a flower cluster, is highly desirable in cherry tomato (Ramya et al., 2016). High yield of open field cherry tomato is the primary criterion of growers for selection of variety.

Few locules in fruit is preferable, as it leads to fruit having the proper shape, and favors high concentrations of solids and ascorbic acid (Thamburaj, 1998). Flesh thickness determines fruit shape and firmness. This is probably due to diversion of photo-assimilates from formation of locule walls towards pericarp formation increasing fruit firmness. Fruit firmness is correlated with fruit quality parameters (color, shape, appearance) (Mukherjee, 2019). Firm fruited genotypes generally have longer shelf-life due to thicker pericarp (Prema et al., 2011).

The main flavor determining parameters of cherry tomato are soluble solids, soluble sugar (fructose+glucose), organic acid (mainly citric acid) and vitamin C (Renuka et al., 2014). A primary determinant of cherry tomato flavor is the ratio of sugars to acids. Fructose and citric acid are more important to sweetness and sourness than glucose and malic acid, respectively (Stevens et al., 1977). Titratable acidity makes for more tart taste which is preferred by the consumers. Cherry tomatoes contain higher amount of vitamin $\mathrm{C}$ than normal tomato (Nuez, 1999). Vitamin C is involved in synthesis of collagen, metal ion metabolism, antihistamine reactions, and enhancement of immune system (Combs, 1992). Lycopene is responsible for the characteristic deep red color of ripe cherry tomato fruit and acts as an antioxidant. Lycopene pigment in cherry tomato fruit decides the optimum stage of ripening and serves as an important criterion for direct consumption as salad. Although lycopene has no provitamin A activity, it exhibits a physical quenching rate constant with singlet oxygen almost twice as high as that of $\beta$ - 
carotene. Cherry tomato, with high $\beta$-carotene content, provides a dietary source of provitamin A (Stommel et al., 2005; Lenucci et al., 2006; Kavitha et al., 2014; Najeema et al., 2018). Cherry tomatoes harvested at full ripeness exhibited the highest level of carotenoids (Raffo et al., 2002). Vitamin A represents a family of compounds structurally like, and having the essential functions, and biological activity, of retinol, which is not well known in cherry tomato. High antioxidant activity in cherry tomato prevents harmful lipid peroxidation initiated by ROS leading to cell damage (Lenucci et al., 2006).

Leaf curl virus of tomatoes, transmitted by whitefly (Bemisia tabaci), caused by Begomoviruses, causes yield loss up to $100 \%$ (Green and Kalloo, 1994). Cherry tomato suffers from leaf curl disease when grown under open field (Dhaliwal and Jindal, 2017; Mukherjee et al., 2019). Problems arising from frequent use of pesticides for control of ToLCV disease have forced growers to find alternative approaches to disease control in integrated disease management, and use of resistant varieties is an ideal solution.

Few report on disease severity of tomato leaf curl virus in cherry tomato lines are available (Mukherjee et al., 2019). Genotypes 16/ToCVAR-1, Cherry Round Yellow, 16/ToCVAR-4 and 16/ToCVAR-3 were identified as resistant as categorized by Cao et al., (2009).

Based on average performance genotypes Cherry Round Yellow and 16/ToCVAR-1 were most promising in respect to fruit yield, better nutritional quality traits and tolerance against ToLCV disease under open field conditions. These genotypes may be utilized after extensive testing over tropical and subtropical production conditions to verify their worth as varieties.

\section{Analysis of genetic variability and character associationship}

Phenotypic coefficient of variation (PCV) and genotypic coefficient of variation (GCV) are categorized as low (0-10\%), moderate (10$20 \%)$ and high $(>20 \%)$ as indicated by Sivasubramanian and Madhava Menon (1973) although, this classification is not rigid. Phenotypic co-efficient of variation agreed closely with GCV for all characters studied (Table 4). The contribution toward final phenotypic expression of studied characters was mostly due to genetic makeup of genotypes rather than environmental factors. This indicates genetic manipulation could produce genotypes suitable for field cultivation.

The magnitude of PCV was higher than GCV for all characters, indicating existence of inherent variability that remains unaltered by environmental conditions among genotypes, which is more useful for exploitation in selection and hybridization (Prema et al., 2011). High PCV and GCV values were recorded for number of locule per fruit, pericarp thickness, fruit firmness, ascorbic acid content of fruit, titratable acidity content of fruit, total antioxidant activity of fruit, PDI of ToLCV and fruit yield per plant which agrees with Prema et al., (2011) and Renuka et al., (2017).

Moderate PCV and GCV values were observed for rest of the characters. High to moderate magnitude of GCV and PCV generally indicated ample opportunity for improvement of cherry tomato through selection. Traits whose expressions are environmentally dependent may not be reliable descriptors for development of genotypes for field production. The concept of heritability is important to evaluate relative magnitude of effects of genes and environments on total phenotypic variability. 
For this reason, genetic variability, along with heritability, should be considered to assess the maximum and accurate effect of selection (Burton 1952). Heritability is classified as low $(<30 \%)$, medium (30-60\%) and high $(>60 \%)$ (Johnson et al., 1955). Very high broad sense heritability values occurred for all characters under study except number of flower cluster per plant and number of fruit per flower cluster (Table 4). High heritability estimates for most of the characters indicate less environmental influence in the observed variation indicating selection based on phenotypic expression could be relied upon to develop genotypes for field production (Panse, 1957).

However, broad sense heritability values were likely to be overestimated as it was not possible to exclude variation due to different genetic components and their interrelations. Genetic advance (GA) was very high (>20.0\%) for all characters under study except number of locule per fruit (Table 4). Pericarp thickness, fruit firmness, ascorbic acid content of fruit, titratable acidity content of fruit, total antioxidant activity of fruit, PDI of ToLCV and fruit yield per plant were characterized by high GCV, heritability and genetic advance. These observations support Islam et al., (2012), Renuka et al., (2017) and Doddamani et al., (2017).

Moderate heritability, accompanied with high genetic advance, for expression of number of flower cluster per plant and number of fruit per flower cluster, indicated these characters were less influenced by environment than genetics. Selection based on these characters for genotypes stable under field conditions would be effective. Direct selection will bring no, or slow, genetic improvement for this trait. Heterosis breeding would be best for improvement of these traits. Phenotypic and genotypic correlation coefficients, in general, agreed closely indicating little influence of environment on the correlated response on most of the paired fruit and fruit quality characters (Table 5). In general, genotypic correlations were higher than phenotypic correlations. Of the characters studied, only number of fruit per cluster and number of fruit per plant exhibited significantly positive correlation with fruit yield per plant which agrees with Sari et al., (2017) and Sanchez et al., (2018). Number of flower clusters per plant, fruit weight, fruit diameter, number of locule per fruit, ascorbic acid content of fruit, titratable acidity content of fruit, $\beta$-carotene content of fruit, RAE and PDI of ToLCV exhibited negative correlation with fruit yield per plant (Table 5). There were few significant correlation coefficients in the positive or negative direction (Table 5).

There would be less likelihood of high yielding cherry tomato genotypes with more flower clusters, bigger size fruit, high contents of ascorbic acid, titratable acidity, $\beta$ carotene, and retinal activity equivalents in fruit. Positive correlation between lycopene and ascorbic acid contents indicated multilocular fruit had higher ascorbic acid content than bilocular fruit which tended to have more lycopene. Number of fruit per cluster and number of fruit per plant were identified as the most important yield component traits, but were not significantly correlated with any of the fruit quality characters indicating different physiological mechanisms and genetic control for quality characters of cherry tomato fruit. Selection based on any of the significantly, positive, inter-related characters would be expected to give a desired correlated response in other characters.

Phenotypic correlation coefficients were partitioned into direct and indirect effects to identify relative importance of yield components towards fruit yield of cherry tomato (Table 5). Among yield component 
traits, number of fruit per flower cluster, pericarp thickness, fruit firmness and number of flower cluster per plant showed high positive direct effects on fruit yield per plant (Table 5).

This was the main cause of their positive association with fruit yield per plant. Direct effects of fruit weight and RAE were high via number of fruit per plant, pericarp thickness, and TSS content of fruit, respectively but their association with fruit yield were negative. Direction selection based on these characters will be effective. Path analysis indicated direct selection based on number of fruit per flower cluster, pericarp thickness, fruit firmness, number of flower cluster per plant, fruit weight and RAE would be beneficial for yield improvement of field grown cherry tomato. Residual effect of path analysis was low indicating inclusion of maximum fruit yield influenced characters.

\section{Multivariate analysis}

Based on determination of divergence, all genotypes could be grouped into 5 Clusters (Table 6). Cluster II had 7 genotypes followed by Cluster I with 3 genotypes, Cluster III with 2 genotypes, and Clusters IV and V were monotypic. The monotypic genotypes in Cluster IV, and V indicated genotypes from those clusters might have originated across the geographical location. Grouping genotypes into 5 clusters indicated geographical diversity and genetic divergence were unrelated. The genotypes could not be grouped into 4-5 clusters which agreed with Aguirre and Cabrera (2012) and Maciel et al., (2018). Environmental influence on composition of cluster was reported earlier in tomato (Peter and Rai, 1976) and cherry tomato (Aguirre et al., 2017). The clustering of breeding lines did not maintain a distribution pattern that is related to the geographical area of origin. The absence of relationship between cluster grouping and geographical distance indicates that exchange of genetic stock, genetic drift, spontaneous mutation, natural and artificial selection might be responsible for such genetic diversity. Selection of genotypes for hybridization should be based on genetic divergence rather than geographic diversity. Intra- and intercluster distances among genotypes (Table 7) indicated Cluster II had the most intra-cluster values indicating genotypes included in the cluster were extremely diverse. Cluster III had minimum intra-cluster values.

Minimum inter-cluster level values between Clusters I and III indicated close relationship among genotypes in those clusters. The greatest inter-cluster values were between Clusters I and IV followed by the distance between Clusters III and VI indicating that genotypes in those clusters had the greatest divergence. Crosses between selected varieties from widely separated clusters were most likely to give desirable recombinants (Kalloo et al., 1980).

Cluster means of genotypes (Table 8) varied in magnitude for all characters. The highest cluster mean was in Cluster IV for fruit yield per plant along with total antioxidant activity of fruit, number of fruit per plant, number of flower cluster per plant, and number of fruit per flower cluster. The minimum severity of ToLCV disease was in Cluster IV. The maximum mean in Cluster I was for $\beta$ carotene, lycopene, titratable acidity contents, and RAE. Cluster III had the lowest number of days to $50 \%$ flowering. Clusters with high mean values could be sources of genes for simultaneous improvement of fruit yield, fruit quality and disease tolerance. A high yielding, early flowering, field grown cherry tomato type, with better fruit quality, and increased resistance to ToLCV disease, could be developed utilizing genotypes from Clusters III and IV as parents. 
Titratable acidity content of fruit contributed the most towards genetic divergence followed by fruit yield per plant, PDI of ToLCV, fruit weight, total antioxidant activity, number of fruit per plant, lycopene content and fruit firmness indicating the possibility for selection of these characters (Table 8).

Diversity analysis of cherry tomato accessions reported here had some similarity to other results for average fruit weight, fruit shape (Rodríguez et al., 2003); fruit yield, average fruit weight, pericarp thickness (Garzón, 2011); fruit number, yield, fruit firmness, vitamin $C$, titratable acidity, lycopene contents (Aguirre and Cabrera, 2012); stem diameter, total chlorophyll content of leaf during flowering and fruiting, fruit yield and average fruit weight (Maciel et al., 2018) contributed most to expression of variability from other locations.

In field grown cherry tomato, leaf curl disease severity trait could be considered as reliable as some fruit physico-chemical traits for assessment of genetic diversity. The titratable acidity content, fruit yield per plant, PDI of ToLCV, and total antioxidant acidity that explained $100 \%$ of contribution towards divergence, and variable loadings for components PC1 (titratable acidity content), PC2 (fruit yield per plant), PC3 (PDI of ToLCV), and PC4 (total antioxidant acidity) were used (Table 9) because their eigen values $>1.0$ and explained $100.0 \%$ of total variance.

Table.1 Analysis of variance for quantitative characters of cherry tomato

\begin{tabular}{|c|c|c|c|}
\hline & \multicolumn{3}{|c|}{ Mean sum of square } \\
\hline & Replication & Treatment & Error \\
\hline Source of variation & $2 \mathrm{df}$ & $13 \mathrm{df}$ & $26 \mathrm{df}$ \\
\hline Days to $50 \%$ flowering & 0.333 & $315.238 * *$ & 78.333 \\
\hline Number of flower cluster per plant & 55.993 & $1584.741 * *$ & 366.465 \\
\hline Number of fruit per flower cluster & 0.147 & $1344.806 * *$ & 63.953 \\
\hline Fruit weight $(g)$ & 0.442 & $6988.263 * *$ & 62.284 \\
\hline Polar diameter $(\mathbf{m m})$ & 1.198 & $2579.704 * *$ & 77.232 \\
\hline Equatorial diameter (mm) & 0.366 & $3598.995 * *$ & 54.056 \\
\hline Number of fruit per plant & 647.478 & $458998.948 * *$ & 15133.606 \\
\hline Number of locule per fruit & 0.001 & 0.001 & 0.001 \\
\hline Pericarp thickness (mm) & 0.104 & $25.518 * *$ & 4.849 \\
\hline Fruit firmness $\left(\mathrm{kg} / \mathrm{cm}^{2}\right)$ & 0.001 & $4.817 * *$ & 1.692 \\
\hline Total soluble solids content $\left({ }^{\circ}\right.$ Brix) & 0.054 & $61.491 * *$ & 5.156 \\
\hline Ascorbic acid content (mg/100 g) & 1.996 & $4207.132 * *$ & 187.429 \\
\hline Titratable acidity content $(\%)$ & 0.000 & $1.674 * *$ & 0.010 \\
\hline Lycopene content (mg/100 g) & 0.000 & $1.013 * *$ & 0.067 \\
\hline$\beta$-carotene content $(\mathrm{mg} / \mathbf{1 0 0} \mathrm{g})$ & 0.000 & 0.361 & 0.019 \\
\hline Retinol activity equivalent & 41.418 & $89157.482 * *$ & 5125.787 \\
\hline Total antioxidant activity (mg/100 g) & 36.402 & $131879.931 * *$ & 5556.224 \\
\hline $\begin{array}{l}\text { Percent disease index of tomato leaf curl } \\
\text { virus }(\%) \text { at } 120 \mathrm{DAT}^{\mathrm{a}}\end{array}$ & 3.862 & $4545.726 * *$ & 75.724 \\
\hline Fruit yield per plant (kg/plant) & 0.064 & $4.911 * *$ & 1.425 \\
\hline
\end{tabular}


Table.2 Mean performance of cherry tomato genotypes for reproductive characters and fruit yield

\begin{tabular}{|c|c|c|c|c|c|c|c|c|c|c|c|}
\hline Genotype & $\begin{array}{l}\text { Days to } 50 \% \\
\text { flowering }\end{array}$ & $\begin{array}{c}\text { Number of } \\
\text { flower cluster } \\
\text { per plant }\end{array}$ & $\begin{array}{c}\text { Number of } \\
\text { fruit per } \\
\text { flower } \\
\text { cluster }\end{array}$ & $\begin{array}{c}\text { Fruit } \\
\text { weight } \\
\text { (g) }\end{array}$ & $\begin{array}{c}\text { Polar } \\
\text { diameter } \\
(\mathbf{m m})\end{array}$ & $\begin{array}{l}\text { Equatorial } \\
\text { diameter } \\
(\mathrm{mm})\end{array}$ & $\begin{array}{l}\text { Number of } \\
\text { fruit per } \\
\text { plant }\end{array}$ & $\begin{array}{l}\text { Number } \\
\text { of locule } \\
\text { per fruit }\end{array}$ & $\begin{array}{c}\text { Pericarp } \\
\text { thickness } \\
(\mathbf{m m})\end{array}$ & $\begin{array}{c}\text { Fruit } \\
\text { firmness } \\
\left(\mathrm{kg} / \mathrm{cm}^{2}\right)\end{array}$ & $\begin{array}{c}\text { Fruit } \\
\text { yield per } \\
\text { plant } \\
\text { (kg/plant) }\end{array}$ \\
\hline 16/ToCVAR-1 & $26.00 \mathrm{edc}^{* \mathrm{a}}$ & $11.29 \mathrm{edcf}$ & $17.00 \mathrm{ba}$ & $11.25 \mathrm{cb}$ & $29.60 \mathrm{~cd}$ & $21.86 \mathrm{gf}$ & $190.16 \mathrm{cb}$ & $3.00 \mathrm{a}$ & $2.51 \mathrm{bcd}$ & $1.26 \mathrm{ba}$ & $2.14 \mathrm{a}$ \\
\hline 16/ToVCAR-2 & $25.00 \mathrm{ed}$ & 11.18edcf & $16.00 \mathrm{bc}$ & $7.98 \mathrm{~cd}$ & 23.55 fge & $25.26 \mathrm{cbfd}$ & $173.87 \mathrm{cbd}$ & $3.00 \mathrm{a}$ & $2.40 \mathrm{bcd}$ & $0.95 \mathrm{bac}$ & $1.38 \mathrm{bc}$ \\
\hline 16/ToCVAR-3 & $26.00 \mathrm{edc}$ & $9.65 \mathrm{edcf}$ & $20.00 \mathrm{ba}$ & $10.74 \mathrm{cb}$ & $20.23 \mathrm{gh}$ & $22.85 \mathrm{ef}$ & $191.39 \mathrm{~b}$ & $2.00 \mathrm{~b}$ & $2.59 \mathrm{bcd}$ & $0.50 \mathrm{bdc}$ & $2.05 \mathrm{ba}$ \\
\hline 16/ToCVAR-4 & 28.00ebdac & $20.35 \mathrm{bac}$ & $8.40 \mathrm{de}$ & $12.27 \mathrm{cb}$ & $27.90 \mathrm{cde}$ & $29.93 b$ & $172.17 \mathrm{cbd}$ & $2.00 \mathrm{~b}$ & $2.77 \mathrm{bc}$ & $0.80 \mathrm{bdac}$ & $2.12 \mathrm{a}$ \\
\hline 16/ToCVAR-5 & $30.00 \mathrm{bdac}$ & 16.78ebdac & 9.80de & $10.53 \mathrm{cb}$ & $35.95 b$ & 23.29efd & $165.95 \mathrm{cbd}$ & $2.00 \mathrm{~b}$ & $2.87 b c$ & $1.28 \mathrm{a}$ & $1.73 \mathrm{ba}$ \\
\hline 16/ToCVAR-6 & $31.00 \mathrm{bac}$ & $8.67 \mathrm{edf}$ & $17.40 \mathrm{ba}$ & $12.89 \mathrm{~b}$ & $32.16 \mathrm{cb}$ & $21.59 \mathrm{gf}$ & $150.79 \mathrm{cbd}$ & $3.00 \mathrm{a}$ & $3.20 \mathrm{ba}$ & $0.40 \mathrm{bc}$ & $1.93 \mathrm{ba}$ \\
\hline 17/ToCVAR-1 & $33.00 \mathrm{a}$ & 14.69ebdacf & 8.90de & $10.37 \mathrm{cb}$ & $22.34 \mathrm{fgh}$ & $21.37 \mathrm{gf}$ & $125.64 \mathrm{cbd}$ & $2.00 \mathrm{~b}$ & $1.40 \mathrm{ed}$ & $0.30 \mathrm{dc}$ & $1.29 \mathrm{c}$ \\
\hline 17/ToCVAR-2 & $27.67 \mathrm{ebdc}$ & 19.95bdac & $6.00 \mathrm{e}$ & $12.16 \mathrm{cb}$ & $33.05 \mathrm{cb}$ & 26.69 cebd & $113.06 \mathrm{~d}$ & $2.00 \mathrm{~b}$ & $1.89 \mathrm{ecd}$ & $0.45 \mathrm{dc}$ & $1.36 \mathrm{bc}$ \\
\hline 17/ToCVAR-4 & $26.00 \mathrm{edc}$ & $20.24 \mathrm{bac}$ & $6.00 \mathrm{e}$ & $10.83 \mathrm{cb}$ & 26.88fde & 26.37cebd & $118.75 \mathrm{~cd}$ & $3.00 \mathrm{a}$ & 2.10becd & $0.16 \mathrm{~d}$ & $1.27 \mathrm{c}$ \\
\hline 17/ToCVAR-5 & $23.00 \mathrm{e}$ & $7.85 \mathrm{ef}$ & $20.00 \mathrm{ba}$ & $8.92 \mathrm{cb}$ & 24.44fgde & $27.58 \mathrm{cbd}$ & $156.55 \mathrm{cbd}$ & $2.00 \mathrm{~b}$ & 1.99becd & $0.70 \mathrm{bdac}$ & $1.39 b c$ \\
\hline 17/ToCVAR-6 & 28.00ebdac & $23.45 \mathrm{ba}$ & $6.10 \mathrm{e}$ & $9.10 \mathrm{cb}$ & $29.38 \mathrm{~cd}$ & $28.97 \mathrm{cb}$ & $138.55 \mathrm{cbd}$ & $3.00 \mathrm{a}$ & $2.05 \mathrm{becd}$ & $0.94 \mathrm{bac}$ & $1.22 \mathrm{c}$ \\
\hline Cherry Round Red & $27.00 \mathrm{ebdc}$ & $12.75 \mathrm{ebdcf}$ & $11.50 \mathrm{dc}$ & $12.06 \mathrm{cb}$ & 22.74fghe & 26.20 cebd & $146.22 \mathrm{cbd}$ & $2.00 \mathrm{~b}$ & $2.89 \mathrm{bc}$ & $1.00 \mathrm{bac}$ & $1.59 \mathrm{ba}$ \\
\hline Cherry Round Yellow & $32.00 \mathrm{ba}$ & $24.86 \mathrm{a}$ & $21.00 \mathrm{a}$ & $4.24 d$ & $17.80 \mathrm{~h}$ & $17.80 \mathrm{~g}$ & $517.15 \mathrm{a}$ & $2.00 \mathrm{~b}$ & $1.02 \mathrm{e}$ & $0.40 \mathrm{dc}$ & $2.15 \mathrm{a}$ \\
\hline $\begin{array}{l}\text { Cherry Round Red } \\
\text { Big Fruit }\end{array}$ & 30.00bdac & $3.87 f$ & $5.90 \mathrm{e}$ & $29.65 a$ & $50.20 \mathrm{a}$ & $58.30 \mathrm{a}$ & $51.93 \mathrm{e}$ & $3.00 \mathrm{a}$ & $4.32 \mathrm{a}$ & $0.66 \mathrm{bdac}$ & $1.54 \mathrm{ba}$ \\
\hline Mean & 28.05 & 14.68 & 12.43 & 13.79 & 28.30 & 27.00 & 172.29 & 2.43 & 2.43 & 0.70 & 1.65 \\
\hline C.V.b $(\%)$ & 6.19 & 15.57 & 12.62 & 11.23 & 6.09 & 5.34 & 14.17 & 1.30 & 7.78 & 6.44 & 14.16 \\
\hline
\end{tabular}


Table.3 Mean performance of cherry tomato genotypes for fruit quality attributes and disease severity

\begin{tabular}{|c|c|c|c|c|c|c|c|c|}
\hline Genotype & $\begin{array}{l}\text { Total soluble } \\
\text { solids ( }{ }^{\circ} \text { Brix) }\end{array}$ & $\begin{array}{c}\text { Ascorbic acid } \\
\text { content } \\
(\mathbf{m g} / 100 \mathrm{~g})\end{array}$ & $\begin{array}{c}\text { Titratable } \\
\text { acidity } \\
\text { content }(\%)\end{array}$ & $\begin{array}{l}\text { Lycopene } \\
\text { content } \\
(\mathrm{mg} / 100 \mathrm{~g})\end{array}$ & $\begin{array}{c}\beta \text {-carotene } \\
\text { content } \\
(\mathrm{mg} / 100 \mathrm{~g})\end{array}$ & $\begin{array}{c}\text { Retinol } \\
\text { activity } \\
\text { equivalent }\end{array}$ & $\begin{array}{c}\text { Total } \\
\text { antioxidant } \\
\text { activity } \\
(\mathbf{m g} / \mathbf{1 0 0} \text { g) }\end{array}$ & $\begin{array}{c}\text { PDI of tomato } \\
\text { leaf curl virus } \\
\text { at } 120 \mathrm{DAT}^{\mathrm{c}} \\
(\%)\end{array}$ \\
\hline 16/ToCVAR-1 & $6.89 \mathrm{edc}^{\mathrm{a}}$ & $32.14 \mathrm{bec}$ & $0.10 \mathrm{~h}$ & $1.18 \mathrm{cbd}$ & $0.52 \mathrm{edf}$ & $260.63 \mathrm{edf}$ & $259.08 \mathrm{a}$ & $8.24 \mathrm{~g}$ \\
\hline 16/ToCVAR-2 & 6.97edc & $37.50 \mathrm{bdac}$ & $0.26 f$ & 1.06gfed & $0.47 \mathrm{egf}$ & $235.80 \mathrm{egf}$ & $257.47 \mathrm{a}$ & 31.20bdac \\
\hline 16/ToCVAR-3 & $7.60 \mathrm{bdc}$ & 29.46de & $0.26 f$ & $0.97 \mathrm{gh}$ & $0.45 \mathrm{gf}$ & $223.39 \mathrm{gf}$ & $135.10 \mathrm{~b}$ & $9.73 \mathrm{~g}$ \\
\hline 16/ToCVAR-4 & $5.98 \mathrm{ef}$ & $20.54 \mathrm{fg}$ & $0.38 \mathrm{~d}$ & $1.03 \mathrm{gfe}$ & $0.36 \mathrm{~h}$ & 179.96h & $134.56 \mathrm{~b}$ & $8.76 \mathrm{~g}$ \\
\hline 16/ToCVAR-5 & $6.74 \mathrm{edc}$ & $38.39 \mathrm{bac}$ & $0.19 \mathrm{~g}$ & $1.00 \mathrm{gf}$ & $0.50 \mathrm{egdf}$ & $248.00 \mathrm{egdf}$ & $131.86 b$ & $21.79 \mathrm{fe}$ \\
\hline 16/ToCVAR-6 & $8.60 \mathrm{ba}$ & $25.00 \mathrm{fe}$ & $0.32 \mathrm{e}$ & $0.84 h$ & $0.51 \mathrm{edf}$ & $254.42 \mathrm{edf}$ & $135.10 \mathrm{~b}$ & $19.21 \mathrm{f}$ \\
\hline 17/ToCVAR-1 & $7.50 \mathrm{bdc}$ & $15.18 \mathrm{gh}$ & $0.32 \mathrm{e}$ & $1.00 \mathrm{gf}$ & $0.42 \mathrm{gh}$ & $210.98 \mathrm{gh}$ & $131.32 \mathrm{~b}$ & $33.46 \mathrm{bac}$ \\
\hline 17/ToCVAR-2 & 7.10edc & $24.11 \mathrm{fe}$ & $0.77 b$ & $1.06 \mathrm{gcfed}$ & $0.63 \mathrm{ba}$ & $316.47 \mathrm{ba}$ & $130.24 b$ & $32.22 \mathrm{bac}$ \\
\hline 17/ToCVAR-4 & $4.80 \mathrm{gf}$ & $20.54 \mathrm{fg}$ & $0.51 \mathrm{c}$ & $1.46 \mathrm{a}$ & $0.61 \mathrm{bac}$ & 304.06bac & $133.48 b$ & $35.07 \mathrm{ba}$ \\
\hline 17/ToCVAR-5 & $8.00 \mathrm{bac}$ & $34.82 \mathrm{bdc}$ & $0.38 \mathrm{~d}$ & $1.15 \mathrm{ced}$ & $0.55 \mathrm{edc}$ & $273.04 \mathrm{edc}$ & $127.55 b$ & $30.26 \mathrm{bdc}$ \\
\hline 17/ToCVAR-6 & $4.60 \mathrm{~g}$ & $41.07 \mathrm{ba}$ & $0.83 a$ & $1.12 \mathrm{cfed}$ & $0.56 \mathrm{bdc}$ & $279.24 \mathrm{bdc}$ & $145.71 b$ & $36.26 \mathrm{a}$ \\
\hline Cherry Round Red & 6.30ed & $44.64 a$ & $0.19 \mathrm{~g}$ & $1.31 \mathrm{~b}$ & $0.67 \mathrm{a}$ & $335.09 a$ & $128.87 b$ & $26.87 \mathrm{de}$ \\
\hline Cherry Round Yellow & $6.50 \mathrm{ed}$ & $11.61 \mathrm{~h}$ & $0.38 \mathrm{~d}$ & $0.94 \mathrm{gh}$ & $0.56 \mathrm{bdc}$ & $279.24 \mathrm{bdc}$ & $258.54 a$ & $8.05 \mathrm{~g}$ \\
\hline $\begin{array}{l}\text { Cherry Round Red Big } \\
\text { Fruit }\end{array}$ & $9.00 \mathrm{a}$ & $16.96 f g h$ & $0.32 \mathrm{e}$ & $1.21 \mathrm{cb}$ & $0.35 \mathrm{~h}$ & $173.75 \mathrm{~h}$ & $253.15 a$ & $28.72 \mathrm{dc}$ \\
\hline Mean & 6.90 & 28.00 & 0.37 & 1.10 & 0.51 & 255.29 & 168.72 & 23.56 \\
\hline C.V.b $(\%)$ & 6.46 & 9.59 & 5.20 & 4.64 & 5.36 & 5.50 & 8.66 & 10.24 \\
\hline
\end{tabular}

${ }^{a}$ values in columns followed by the same letter are not significantly different, $p<0.0001$, Tukey's post hoc test.

${ }^{\mathrm{b}} \mathrm{C} . \mathrm{V} .=$ Coefficient of variation. $\quad{ }^{\mathrm{c}} \mathrm{DAT}=$ Days after transplanting. 
Table.4 Estimates of genetic parameters of cherry tomato genotypes

\begin{tabular}{|c|c|c|c|c|c|}
\hline Character & $\begin{array}{c}\mathbf{G C V}^{\mathrm{a}} \\
(\%)\end{array}$ & $\begin{array}{c}\mathbf{P C V}^{\mathrm{b}} \\
(\%)\end{array}$ & $\begin{array}{c}\text { GCV:P } \\
\text { CV }\end{array}$ & $\begin{array}{l}h^{2} \text { in broad } \\
\text { sense }^{c}(\%)\end{array}$ & $\begin{array}{c}\text { Genetic } \\
\text { advance as } \\
(\%) \text { of mean }\end{array}$ \\
\hline Days to $50 \%$ flowering & 12.42 & 12.94 & 95.97 & 92.10 & 24.55 \\
\hline Number of flower clusters per plant & 16.48 & 18.46 & 89.30 & 79.80 & 30.32 \\
\hline Number of fruit per flower cluster & 13.61 & 14.79 & 91.98 & 84.60 & 25.78 \\
\hline Fruit weight (g) & 12.47 & 13.09 & 95.26 & 90.70 & 24.48 \\
\hline Polar diameter $(\mathbf{m m})$ & 19.49 & 19.57 & 99.59 & 99.20 & 39.97 \\
\hline Equatorial diameter (mm) & 17.72 & 17.88 & 99.08 & 98.20 & 36.17 \\
\hline Number of fruit per plant & 17.92 & 18.83 & 95.13 & 90.50 & 35.11 \\
\hline Number of locule per fruit & 21.15 & 21.20 & 99.75 & 99.90 & 1.06 \\
\hline Pericarp thickness (mm) & 28.30 & 28.74 & 98.46 & 96.90 & 57.40 \\
\hline Fruit firmness $\left(\mathrm{kg} / \mathrm{cm}^{2}\right)$ & 47.54 & 49.29 & 96.44 & 93.00 & 94.45 \\
\hline Total soluble solids content ( $\left.{ }^{0} \mathrm{brix}\right)$ & 14.51 & 14.98 & 96.87 & 93.80 & 28.96 \\
\hline Ascorbic acid content (mg/100 g) & 30.47 & 31.22 & 97.60 & 95.30 & 61.27 \\
\hline Titratable acidity content (\%) & 27.86 & 28.09 & 99.21 & 98.40 & 56.94 \\
\hline Lycopene content (mg/100 g) & 18.43 & 19.32 & 95.38 & 91.00 & 36.21 \\
\hline$\beta$-carotene content $(\mathrm{mg} / 100 \mathrm{~g})$ & 19.75 & 20.67 & 95.54 & 91.30 & 38.87 \\
\hline Retinol activity equivalent & 19.45 & 20.44 & 95.17 & 90.60 & 38.14 \\
\hline Total antioxidant activity $(\mathrm{mg} / \mathbf{1 0 0} \mathrm{g})$ & 28.66 & 29.17 & 98.22 & 96.50 & 57.98 \\
\hline $\begin{array}{l}\text { PDI of tomato leaf curl virus (\%) at } \\
120 \text { DAT }^{d}\end{array}$ & 42.87 & 42.91 & 99.91 & 99.80 & 88.24 \\
\hline Fruit yield per plant (kg/plant) & 20.56 & 21.19 & 97.03 & 94.10 & 41.09 \\
\hline
\end{tabular}


Table.5 Genotypic and phenotypic correlations, phenotypic inter-relationship and direct effects of 18 characters on fruit yield per plant

\begin{tabular}{|c|c|c|c|c|c|c|c|c|c|c|c|c|}
\hline Character & $\begin{array}{c}\text { rga }^{\mathrm{a}} \\
\text { with } \\
\text { yield } \\
\text { per } \\
\text { plant }\end{array}$ & $\begin{array}{c}\text { rp }^{\mathbf{b}} \\
\text { with } \\
\text { yield per } \\
\text { plant }\end{array}$ & $\begin{array}{c}\text { rp with } \\
\text { number of } \\
\text { fruit per } \\
\text { flower } \\
\text { cluster }\end{array}$ & $\begin{array}{c}\text { rp with } \\
\text { number } \\
\text { of fruit } \\
\text { per plant }\end{array}$ & $\begin{array}{l}\text { rp with } \\
\text { total } \\
\text { soluble } \\
\text { solids }\end{array}$ & $\begin{array}{l}\text { rp with } \\
\text { ascorbic } \\
\text { acid } \\
\text { content }\end{array}$ & $\begin{array}{l}\text { rp with } \\
\text { titratable } \\
\text { acidity } \\
\text { content }\end{array}$ & $\begin{array}{l}\text { rp with } \\
\text { lycopene } \\
\text { content }\end{array}$ & $\begin{array}{l}\text { rp with } \beta \text { - } \\
\text { carotene } \\
\text { content }\end{array}$ & $\begin{array}{c}\text { rp with } \\
\text { retinol } \\
\text { activity } \\
\text { equivalent }\end{array}$ & $\begin{array}{l}\text { rp with total } \\
\text { antioxidant } \\
\text { activity }\end{array}$ & $\begin{array}{c}\text { Direct effect of } \\
\text { characters on } \\
\text { yield per plant } \\
\text { at phenotypic } \\
\text { level }\end{array}$ \\
\hline D50F & -0.207 & -0.169 & -0.201 & 0.231 & 0.173 & $-0.558^{*}$ & 0.001 & -0.481 & -0.276 & -0.272 & 0.054 & -0.122 \\
\hline NFCPP & -0.088 & -0.031 & -0.291 & 0.482 & $-0.802 * *$ & -0.152 & $0.565^{*}$ & -0.014 & 0.352 & 0.360 & -0.157 & 0.688 \\
\hline NFPFC & 0.603 & $0.551 * *$ & 1.000 & $0.614 *$ & 0.360 & 0.069 & -0.493 & -0.432 & 0.039 & 0.035 & 0.279 & 1.607 \\
\hline FW & -0.098 & -0.090 & -0.382 & -0.505 & 0.496 & -0.272 & -0.082 & 0.23 & -0.486 & -0.488 & 0.321 & 0.571 \\
\hline PD & -0.153 & -0.140 & $0.541 *$ & $-0.603 *$ & 0.353 & -0.079 & 0.08 & 0.141 & -0.336 & -0.338 & 0.150 & -0.330 \\
\hline ED & -0.257 & -0.239 & -0.484 & $-0.563 *$ & 0.316 & -0.145 & 0.094 & 0.350 & -0.440 & -0.440 & 0.243 & -0.498 \\
\hline NFPP & 0.555 & $0.542 * *$ & $0.614 *$ & 1.000 & -0.184 & -0.249 & -0.112 & -0.387 & 0.183 & 0.187 & 0.351 & -1.192 \\
\hline NLPF & -0.202 & -0.187 & -0.157 & -0.313 & -0.063 & 0.075 & 0.075 & 0.289 & -0.075 & -0.075 & 0.442 & -0.371 \\
\hline PT & 0.153 & 0.138 & -0.223 & $-0.595^{*}$ & 0.428 & 0.181 & -0.336 & 0.137 & -0.403 & -0.408 & 0.095 & 0.990 \\
\hline FF & 0.166 & 0.180 & 0.034 & -0.048 & -0.118 & $0.721 * *$ & -0.362 & 0.056 & -0.029 & -0.024 & 0.228 & 0.747 \\
\hline TSS & 0.231 & 0.195 & 0.360 & -0.184 & 1.000 & -0.237 & -0.426 & -0.417 & -0.424 & -0.430 & 0.188 & -0.629 \\
\hline $\mathbf{A A C}$ & -0.241 & -0.213 & 0.069 & -0.249 & -0.237 & 1.000 & -0.093 & 0.200 & 0.390 & 0.390 & -0.206 & -1.164 \\
\hline TA & -0.562 & -0.518 & -0.493 & -0.112 & -0.426 & -0.093 & 1.000 & 0.078 & 0.306 & 0.309 & -0.308 & 0.222 \\
\hline LC & -0.500 & -0.453 & -0.432 & -0.387 & -0.417 & 0.2 & 0.078 & 1.000 & 0.369 & 0.369 & -0.005 & -0.144 \\
\hline BCC & -0.300 & -0.274 & 0.039 & 0.183 & -0.424 & 0.39 & 0.306 & 0.369 & 1.000 & $1.000 * *$ & -0.253 & 0.105 \\
\hline RAE & -0.300 & -0.275 & 0.035 & 0.187 & -0.43 & 0.39 & 0.309 & 0.369 & $1.000 * *$ & 1.000 & -0.247 & 0.227 \\
\hline TAA & 0.311 & 0.280 & 0.279 & 0.351 & 0.188 & -0.206 & -0.308 & -0.005 & -0.253 & -0.247 & 1.000 & 0.192 \\
\hline $\begin{array}{l}\text { PDI } \\
\text { ToLCV }\end{array}$ & -1.000 & $-0.991 * *$ & $-0.569 *$ & $-0.575^{*}$ & -0.146 & 0.214 & 0.501 & 0.441 & 0.281 & 0.282 & -0.281 & -0.256 \\
\hline FYPP & - & - & $0.551^{*}$ & $0.542 *$ & 0.195 & -0.213 & -0.518 & -0.453 & -0.274 & -0.275 & 0.280 & - \\
\hline
\end{tabular}

*,** Significant at $P \leq 0.05$ and $P \leq 0.01$, respectively. $\quad{ }^{a}$ rp $=$ Phenotypic correlation coefficient.

${ }^{\mathrm{b}}$ rg = Genotypic correlation coefficient; Residual effect $=0.005$.

$\mathrm{D} 50 \mathrm{~F}=$ Days to 50\% flowering; NFCPP = Number flower clusters per plant; NFPFC = Number fruit per flower cluster; FW = Fruit weight (g); PD = Polar diameter $(\mathrm{mm})$; ED = Equatorial diameter $(\mathrm{mm})$; NFPP = Number fruit per plant; NLPF = Number locules per fruit; PT = Pericarp thickness $(\mathrm{mm})$; FF = Fruit firmness $\left(\mathrm{kg} / \mathrm{cm}^{2}\right)$; TSS = Total soluble solids $\left({ }^{\circ}\right.$ Brix $)$; AAC = Ascorbic acid content $(\mathrm{mg} / 100 \mathrm{~g})$; TA = Titratable acidity content $(\%)$; LC = Lycopene content $(\mathrm{mg} / 100 \mathrm{~g}) ; \mathrm{BCC}=\beta$-carotene content $(\mathrm{mg} / 100 \mathrm{~g}) ; \mathrm{RAE}=$ Retinol activity equivalent; TAA = Total antioxidant activity $(\mathrm{mg}$ Trolox equivalent/ $100 \mathrm{~g}$ fresh weight); PDI of ToLCV = Percent disease index of tomato leaf curl virus (\%) at 120 DAT; FYPP = Fruit yield per plant $(\mathrm{kg})$ 
Table.6 Cluster classification of cherry tomato genotypes

\begin{tabular}{|c|l|}
\hline $\begin{array}{c}\text { Number of } \\
\text { clusters }\end{array}$ & Name of the genotype and source of collection in parentheses \\
\hline I (3) & 17/ToCVAR-2 (Uttar Pradesh), 17/ToCVAR-4 (Uttar Pradesh), Cherry Round Red (West Bengal) \\
\hline II (7) & 16/ToCVAR-3 (Uttar Pradesh), 16/ToCVAR-4 (Uttar Pradesh), 16/ToCVAR-5 (Uttar Pradesh), \\
& 16/ToCVAR-6 (Uttar Pradesh), 17/ToCVAR-5 (Uttar Pradesh), 17/ToCVAR-6 (Uttar Pradesh), \\
& 17/ToCVAR-1(Uttar Pradesh) \\
\hline III (2) & 16/ToCVAR-1(Uttar Pradesh), 16/ToCVAR-2 (Uttar Pradesh) \\
\hline IV (1) & Cherry Round Yellow (West Bengal) \\
\hline V (1) & Cherry Round Red Big Fruit (West Bengal) \\
\hline
\end{tabular}

Table.7 Inter- and intra-cluster distances of cherry tomato genotypes

\begin{tabular}{|c|c|c|c|c|c|}
\hline Cluster & I & II & III & IV & V \\
\hline I & $\mathbf{6 5 . 7 4}$ & 1258.10 & 436.70 & 2093.90 & 4213.19 \\
\hline II & & $\mathbf{2 7 8 . 8 5}$ & 507.02 & 558.05 & 1731.77 \\
\hline III & & & $\mathbf{2 5 . 3 0}$ & 1150.15 & 2521.47 \\
\hline IV & & & & $\mathbf{0 . 0 0}$ & 1623.63 \\
\hline V & & & & & $\mathbf{0 . 0 0}$ \\
\hline
\end{tabular}

${ }^{a}$ Bold diagonal values indicate intra-cluster distance; the remainder of values indicate the inter-cluster distances

Table. 8 Cluster means of characters of cherry tomato genotypes

\begin{tabular}{|c|c|c|c|c|c|c|}
\hline Character & $\begin{array}{l}\text { Cluster } \\
\text { I }\end{array}$ & $\begin{array}{c}\text { Cluster } \\
\text { II }\end{array}$ & $\begin{array}{l}\text { Cluster } \\
\text { III }\end{array}$ & $\begin{array}{l}\text { Cluster } \\
\text { IV }\end{array}$ & $\underset{\mathrm{V}}{\text { Cluster }}$ & $\begin{array}{l}\% \text { contribution } \\
\text { towards divergence }\end{array}$ \\
\hline Days to $50 \%$ flowering & 26.89 & 28.43 & 25.50 & 32.00 & 30.00 & 0.00 \\
\hline Number of flower cluster per plant & 17.65 & 14.49 & 11.24 & 24.86 & 3.87 & 0.00 \\
\hline Number of fruit per flower cluster & 7.83 & 12.94 & 16.50 & 21.00 & 5.90 & 0.00 \\
\hline Fruit weight (g) & 11.68 & 10.69 & 9.62 & 4.24 & 29.65 & 6.59 \\
\hline Polar diameter $(\mathbf{m m})$ & 27.56 & 27.49 & 26.58 & 17.80 & 50.20 & 1.10 \\
\hline Equatorial diameter (mm) & 26.42 & 25.08 & 23.56 & 17.80 & 58.30 & 0.00 \\
\hline Number of fruit per plant & 126.01 & 157.29 & 182.02 & 517.15 & 22.87 & 4.40 \\
\hline Number of locule per fruit & 2.33 & 2.29 & 3.00 & 2.00 & 3.00 & 0.00 \\
\hline Pericarp thickness (mm) & 2.29 & 2.41 & 2.46 & 1.02 & 4.32 & 0.00 \\
\hline Fruit firmness $\left(\mathrm{kg} / \mathrm{cm}^{2}\right)$ & 0.54 & 0.70 & 1.11 & 0.40 & 0.66 & 0.00 \\
\hline Total soluble solids content ( ${ }^{0}$ brix) & 6.07 & 7.00 & 6.93 & 6.50 & 9.00 & 2.20 \\
\hline Ascorbic acid content (mg/100 g) & 29.76 & 29.21 & 34.82 & 11.61 & 16.96 & 1.10 \\
\hline Titratable acidity content (\%) & 0.49 & 0.38 & 0.18 & 0.38 & 0.32 & 48.35 \\
\hline Lycopene content (mg/100 g) & 1.28 & 1.02 & 1.12 & 0.94 & 1.21 & 1.10 \\
\hline$\beta$-carotene content $(\mathbf{m g} / \mathbf{1 0 0} \mathrm{g})$ & 0.64 & 0.48 & 0.50 & 0.56 & 0.35 & 2.20 \\
\hline Retinol activity equivalent & 318.54 & 238.43 & 248.22 & 279.24 & 173.75 & 0.00 \\
\hline Total antioxidant activity $(\mathrm{mg} / \mathbf{1 0 0} \mathrm{g})$ & 130.86 & 134.46 & 258.28 & 258.54 & 253.15 & 6.59 \\
\hline $\begin{array}{l}\text { PDI of tomato leaf curl virus }(\%) \text { at } \\
120 \text { DAT }^{\mathrm{a}}\end{array}$ & 31.39 & 22.78 & 19.72 & 8.05 & 28.72 & 12.09 \\
\hline Fruit yield per plant (kg/plant) & 1.41 & 1.68 & 1.76 & 2.15 & 1.54 & 14.29 \\
\hline
\end{tabular}


Table.9 Results of principal component analysis (PCA) for characters contributing to divergence in cherry tomato

\begin{tabular}{|l|c|c|c|}
\hline $\begin{array}{l}\text { Principal } \\
\text { components }\end{array}$ & Eigenvalue \% & \% Variance & \% Cumulative variance \\
\hline \multicolumn{2}{|l|}{ Eigenvalues and variance accounted for $(\boldsymbol{\%})$} & by PCA based on correlation matrix \\
\hline $\mathbf{P C}_{\mathbf{1}}{ }^{\mathbf{a}}$ & 3410.20710 & 92.69 & 92.69 \\
\hline $\mathbf{P C}_{\mathbf{2}}$ & 177.21685 & 04.82 & 97.51 \\
\hline $\mathbf{P C}_{\mathbf{3}}$ & 90.50605 & 02.46 & 99.97 \\
\hline $\mathbf{P C}_{\mathbf{4}}$ & 1.10985 & 0.030 & 100.00 \\
\hline
\end{tabular}

${ }^{\mathrm{a}} \mathrm{PC}_{1-4}=$ Principal components 1-4

Table.10 Contribution of diverse traits in the principal components of cherry tomato

\begin{tabular}{|c|c|c|c|c|}
\hline Variable & $\mathbf{P C}_{1}^{\mathbf{a}}$ & $\mathbf{P C}_{2}$ & $\mathbf{P C}_{3}$ & $\mathbf{P C}_{4}$ \\
\hline \multicolumn{5}{|c|}{ Factor loadings due to PCs with eigenvalues >1 } \\
\hline Titratable acidity content $(\%)$ & -0.001106 & 0.002593 & 0.008948 & -0.067003 \\
\hline Fruit yield per plant (kg) & 0.001732 & -0.013073 & -0.030330 & 0.006979 \\
\hline $\operatorname{PDI}^{\mathrm{b}}(\%)$ of ToLCV at $120 \mathrm{DAT}^{\mathrm{c}}$ & -0.052783 & 0.442548 & 0.894073 & 0.029338 \\
\hline $\begin{array}{l}\text { Total antioxidant activity (mg/100 } \\
\text { g fresh weight) }\end{array}$ & 0.995651 & -0.045521 & 0.081271 & 0.001221 \\
\hline
\end{tabular}

${ }^{\mathrm{a}} \mathrm{PC}_{1-4}=$ Principal components $1-4 .{ }^{\mathrm{b}} \mathrm{PDI}(\%)$ of ToLCV $=$ Percent disease index (\%) of tomato leaf curl virus.

${ }^{\mathrm{c}} \mathrm{DAT}=$ Days after transplanting

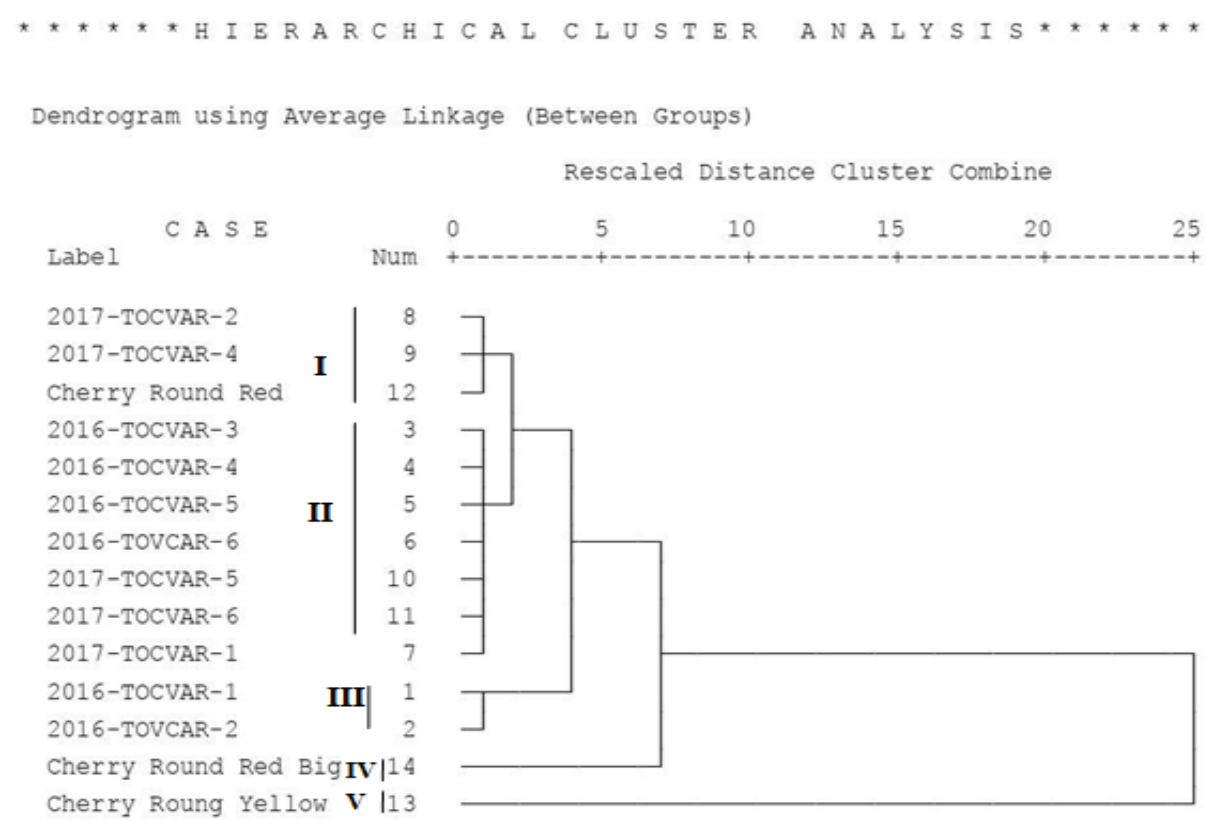

Figure.1 Dendrogram of genotypes of cherry tomato following Ward's method. Genotypes are in left most column. Roman numerals represent Clusters. The top horizontal axis represents the distance, or dissimilarity, based on rescaled distance between clusters. Clusters I, II, and III are branches occurring at about the same horizontal distance. The 2 outliers, 14 and 13, are placed arbitrarily at much higher distances. The vertical axis represents objects and clusters. Each joining (fusion) of 2 clusters is represented by splitting of a horizontal line. The horizontal position of the split, shown by the short vertical bar, is the distance (dissimilarity) between 2 clusters. 


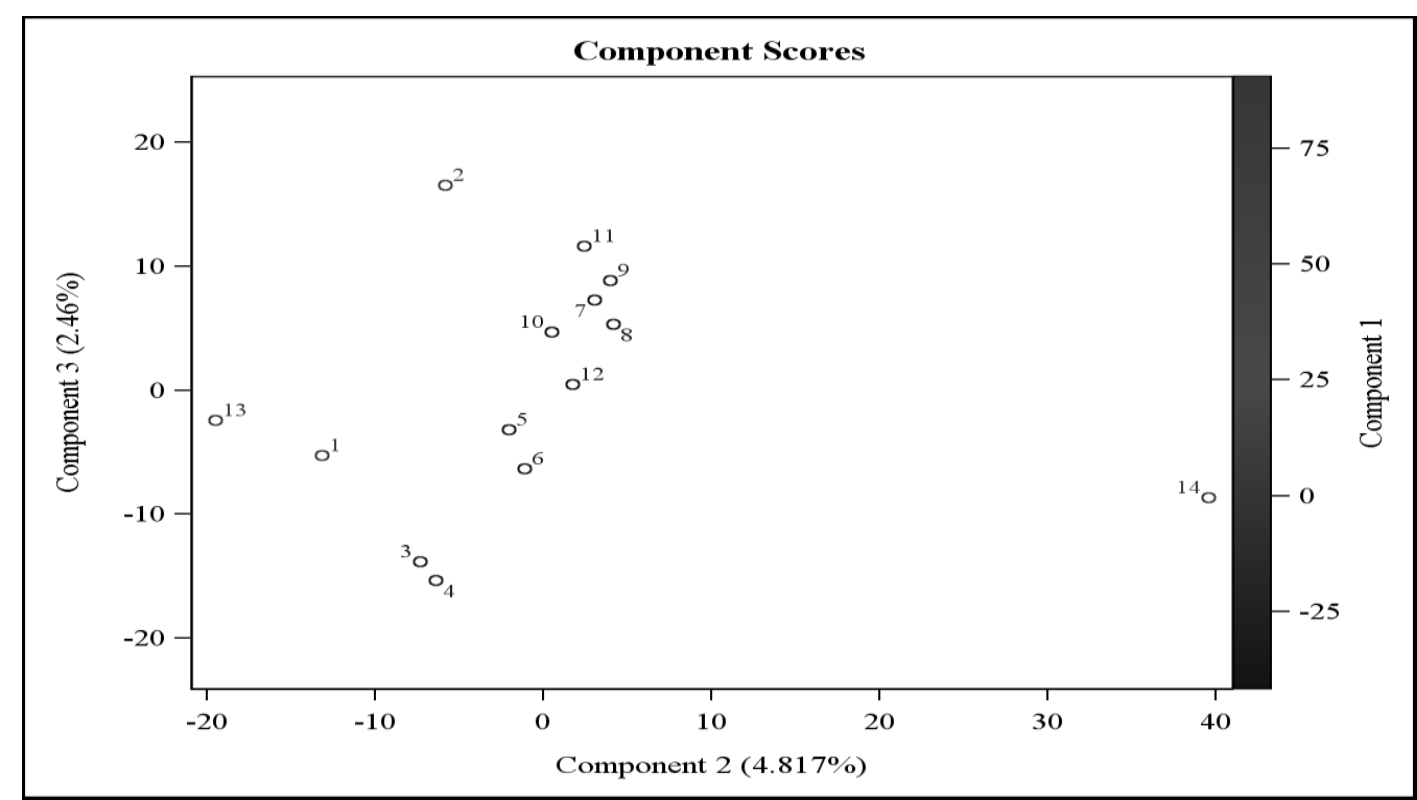

Figure.2 Scatter diagram of regression factor scores for the first and second components as determined by principal component analysis. Points in diagram closest to the intersection of 0 on the $\mathrm{X}$ - and Y-axes indicate similarity. Outliers on the X-axis: $1=16 /$ ToCVAR-1, $2=$ 16/ToCVAR-2, 3 = 16/ToCVAR-3, 4 = 16/ToCVAR-4, 5 = 16/ToCVAR-5, 6 = 16/ToCVAR-6, $13=$ Cherry Round Yellow, and $14=$ Cherry Round Red Big Fruit, indicate diversity. Numbers correspond to the name of the genotype (see Figure 1)

The first component (PC1) explained most of total variance in which a decrease in titratable acidity content leads to increase in fruit yield per plant, total antioxidant activity and decrease in PDI (\%) of ToLCV (Table 10). The second component (PC2) explained an additional, small amount, variance in which a decrease in fruit yield per plant was associated with increased titratable acidity, PDI of ToLCV along with decreased total antioxidant activity. The accessions 16/ToCVAR-1, 16/ToCVAR-2, 16/ToCVAR3, 16/ToCVAR-4, 16/ToCVAR-5, 16/ToCVAR-6, Cherry Round Yellow and Cherry Round Red Big Fruit were quantitatively dissimilar from others.

From the plot of PC1 vs. PC2, PC3 selection may be refined considering all 3 principal components, with 16/ToCVAR-1 being the best performing cultivar having optimum combination of all variables, followed by genotypes 16/ToCVAR-3 and 16/ToCVAR-4 and can be used as potential donors in field grown cherry tomato breeding.

High diversity occurred among cherry tomato genotypes along with strong relationships (Figure 1). The scatter diagram (Figure 2) indicated genotypes 16/ToCVAR-1, 16/ToCVAR-2, 16/ToCVAR-3, 16/ToCVAR4, Cherry Round Yellow and Cherry Round Red Big Fruit have differences of genotypic characters and belong furthest from other genotypes.

The remainder of genotypes had similar features forming a separate cluster. The PCA is used to determine morphological relationships among cherry tomato genotypes (Garzón, 2011; Aguirre and Cabrera 2012). Accessions in close proximity are perceived as being similar in PCA; accessions that are further apart are more diverse. There are no previously reported quantitative studies available on cherry tomato accessions of 
Indian occurrence. The present study indicated quantitative morphological differentiation between accessions. Based on principal component analysis, and average values, genotypes 16/ToCVAR-1, 16/To CVAR-2, 16/ToCVAR-3， 16/ToCVAR-4, Cherry Round Yellow and Cherry Round Red Big Fruit possessed the optimum combination of all variables and can be used as improved genetic material for field grown cherry tomato breeding.

Based on average performance for fruit yield and other horticultural traits, genotypes Cherry Round Yellow and 2016-TOCVAR-1 could be commercialized as open field varieties after critical testing under tropical and sub-tropical conditions of the world. Based on determination of divergence, 14 genotypes could be grouped into 5 clusters emphasizing the relative contribution of various quantitative characters to total variability. The clusters do not represent place of origin indicating genotypes in a cluster were geographically diverse; genotypes obtained from the same region were genetically different.

Six genotypes 16/ToCVAR-1, 16/ToCVAR3, 16/ToCVAR-4, 16/ToCVAR-5, 16/To CVAR-6 and Cherry Round Yellow were identified as potential donors which could make a dent in field grown cherry tomato breeding particularly in tropical and subtropical regions of the world for simultaneous improvement in yield, nutritional quality, and leaf curl virus disease tolerance.

\section{Acknowledgment}

The authors gratefully acknowledge the partial financial support received from the Project Coordinator, All India Coordinated Research Project on Vegetable Crops, Indian Council of Agricultural Research-Indian Institute of Vegetable Research, Varanasi, Uttar Pradesh, India to conduct the study.

\section{References}

Aguirre, N.C. and Cabrera, F.A.V. 2012. Evaluating the fruit production and quality of cherry tomato (Solanum lycopersicum var. cerasiforme). Magazine of the National Faculty of Agronomy Medellín. 65: 6593-6604.

Aguirre, N.C., López, W., Cárdenas, M.O., Coronado, Y.M. and Cabrera, F.A.V. 2017. Use of microsatellites for evaluation of genetic diversity in cherry tomato. Bragantia Campinas. 76: 220228.

Anonymous 1990. Official methods of analysis, vol 1. Association of Official Agricultural Chemist Arlington, VA.

Anonymous 2006. Nutrient reference values for Australia and New Zealand including recommended dietary intakes. Australian National Health and Medical Research Council and the New Zealand Ministry of Health. National Health and Medical Research Council, Canberra, Australia.

Banerjee, M.K. and Kalloo, G. 1987. Sources and inheritance of resistance to leaf curl virus in Lycopersicon. Theoretical and Applied Genetics. 73: 707-710.

Braca, A., Tommasi, N.D.E., Di Bari, L., Pizza, C., Politi, M. and Morelli, I. 2001. Antioxidant principles from Bauhinia tarapotensis. Journal of Natural Products. 64: 892-895.

Burton, G.W. 1952. Quantitative inheritance in grasses. Proceeding 6th International Grassland Congress. 17-23 August 1952. National Publishing Company, Washington, DC.

Cao, B.H., Lei, J.J., Yong, W. and Chen, G.J. 2009. Inheritance and identification of SCAR marker linked to bacterial wiltresistance in eggplant. African Journal of Biotechnology. 8(20): 5201-5207.

Combs, G.F. 1992. The vitamins: fundamental aspects in nutrition and health. Academic Press, Cambridge, MA.

Davies, B.H. 1976. Carotenoids. In: Chemistry and biochemistry of plants (ed. T.W. Goodwin), Academic Press, London, pp. 
38-155.

Dewey, D.R. and Lu, H.K. 1959. A correlation and path-coefficient analysis of components of crested wheat grass production. Agronomy Journal. 51(9): 515-518.

Dhaliwal, M.S. and Jindal, S.K. 2017. Development of cherry tomato variety from interspecific cross (Solanum esculentum and $S$. pimpinellifolium) for protected cultivation. Agricultural Research Journal. 54(2): 182-187.

Doddamani, M.B., Jagadeesha, R.C., Suresh, G.J., Ramanagouda, S.H., Raghunatha Reddy, R.L. and Shet, R. 2017. Studies on genetic variability, heritability and genetic advance for growth, yield and quality traits in $\mathrm{F}_{3}$ population of cherry tomato (Solanum lycopersicum L. var. cerasiforme). International Journal of Pure \& Applied Bioscience. 5: 86-91.

Garzón, J.P. 2011. Characterization and morphoagronomic evaluation of the cherry tomato collection of the National University of Colombia, Faculty of Agricultural Sciences, National University of Colombia, Palmira, Colombia, MS thesis.

Gharezi, M., Joshi, N. and Indiresh, K.M. 2012. Physico-chemical and sensory characteristics of different cultivars of cherry tomato. Mysore Journal of Agricultural Sciences. 46: 610-613.

Gomez, K.A. and Gomez, A.A. 1984. Statistical procedures for agricultural research, 2nd ed. John Wiley Sons, New York.

Green, S.K. and Kalloo, G. 1994. Leaf curl and yellowing viruses of pepper and tomato: An overview, Technical bulletin 21. Asian Vegetable Research and Development Centre, Tainan, Taiwan.

Hanson, C.H., Robinson, H.F. and Comstock, R.E. 1956. Biometrical studies of yield in segregation populations of Korean lespedeza. Agronomy Journal. 48: 268272.

Islam, M.S., Mohanta, H.C., Ismail, M.R., Rafii, M.Y. and Malek, M.A. 2012. Genetic variability and trait relationship in cherry tomato [Solanum lycopersicum L. var. cerasiforme (Dunnal) A. Gray]. Bangladesh Journal of Botany. 41: 163167.

Johnson, H.W., Robinson, H.F. and Comstock, R.E. 1955. Estimates of genetic and environmental variability in soybeans. Agronomy Journal. 47(7): 314-318.

Kalloo, G., Singh, V.P., Dudi, B.S. and Pratap, P.S. 1980. Analysis of variation and genetic diversity in garden peas. Haryana Agricultural University Journal of Research. 10: 540-546.

Kavitha, P., Shivashankara, K.S., Rao, V.K., Sadashiva, A.T., Ravishankar, K.V. and Sathish, G.J. 2014. Genotypic variability for antioxidant and quality parameters among tomato cultivars, hybrids, cherry tomatoes and wild species. Journal of the Science of Food and Agriculture. 94: 993-999.

Kobryn, J. and Hallmann, E. 2005. The effect of nitrogen fertilization on the quality of three tomato types cultivated on Rockwool. Acta horticulturae. 691: 341348.

Lenucci, M., Cadinu, D., Taurino, M., Piro, G. and Dalessandro, G. 2006. Antioxidant composition in cherry and high-pigment tomato cultivars. Journal of Agricultural and Food Chemistry. 54: 2606-2613.

Mahalanobis, P.C. 1936. On the generalized distance in statistics. Proceedings of the National Academy of Sciences. 2: 49-55.

Malik, G., Masoodi, L., Nabi, S.U., Sharma, A. and Singh, D.B. 2017. Production technology of cherry tomato in Kashmir, Indian Council of Agricultural ResearchCentral Institute of Temperate Horticulture, Srinagar, Jammu and Kashmir, India.

Maciel, G.M., Finzi, R.R., Carvalho, F.J., Marquez, G.R., Clemente, A.A. 2018. Agronomic performance and genetic dissimilarity among cherry tomato genotypes. Horticultura Brasileira. 36: 167-172.

McKinney, H.H. and Davis, R.J. 1925. Influence of soil temperature and 
moisture on infection of wheat seedling by Helminthosporium sativum. Journal of Agricultural Research. 26: 195-217.

Medina, C.I. and Lobo, M. 2001. Morphological variability in the tomato bird (Lycopersicon esculentum var. cerasiforme), precursor of the cultivated tomato. Revista Corpoica. 3: 39-50.

Miller, J.C. and Tanksley, S.D. 1990. RFLP analysis of phylogenetic relationships and genetic variation in the genus Lycopersicon. Theoretical and Applied Genetics. 80: 437-448.

Mukherjee, D., Maurya, P.K., Banerjee, S., Bhattacharjee, T., Chatterjee, S., Chatterjee, S., Mandal, A.K., Maji, A. and Chattopadhyay, A. 2019. Breeding cherry tomato grown under open field conditions for simultaneous improvement in yield, nutritional quality, and leaf curl virus disease tolerance. International Journal of Vegetable Science (in press). https://doi.org/10.1080/19315260. 2019.1663973.

Mukherjee, D. 2019. Breeding cherry tomato for higher yield and nutritional qualities. M.Sc. thesis submitted to the Department of Vegetable Science, Bidhan Chandra Krishi Viswavidyalaya, Mohanpur, Nadia, West Bengal, India.

Najeema, M.H., Revanappa, Hadimani H.P. and Biradar, I.B. 2018. Evaluation of cherry tomato (Solanum lycopersicum var. cerasiforme) genotypes for yield and quality traits. International Journal of Current Microbiology and Applied Sciences. 7: 2433-2439.

Nuez, F. 1999. Desarrollo de nuevos cultivares, In: El cultivo del tomate (Cultivation of tomato) (ed. F. Nuez), Mundi-Press, Madrid, Spain, pp. 625-669.

Panse, V.G. 1957. Genetics of quantitative characters in relation to plant breeding. Indian Journal of Genetics and Plant Breeding. 17: 318-328.

Peter, K.V. and Rai, B. 1976. Genetic divergence in tomato. Indian Journal of Genetics and Plant Breeding. 36: 379383.
Prema, G., Indiresh, K.M. and Santosha, H.M. 2011. Evaluation of cherry tomato (Solanum lycopersicum var. cerasiforme) genotypes for growth, yield and quality traits. Asian Journal of Horticulture. 6: 181-184.

Raffo, A., Leonardi, C., Fogliano, V., Ambrosino, P., Salucci, M., Gennaro, L., Bugianesi, R., Giuffrida, F. and Quaglia, G. 2002. Nutritional value of cherry tomatoes (Lycopersicon esculentum cv. Naomi $F_{1}$ ) harvested at different ripening stages. Journal of Agricultural and Food Chemistry. 50: 6550-6556.

Ramya, R., Ananthan, M. and Krishnamoorth, V. 2016. Evaluation of cherry tomato [Solanum lycopersicum L. var. cerasiforme (Dunnal) A. Gray] genotypes for yield and quality traits. Asian Journal of Horticulture. 11: 329-334.

Rao, C.R. 1952. Advanced statistical methods in biometrics. John Wiley Sons, New York.

Renuka, D.M., Sadashiva, A.T. and Jogi, M. 2017. Genetic variability studies in cherry tomato (Solanum lycopersicum L. var. cerasiforme Mill.). International Journal of Current Microbiology and Applied Sciences. 6: 2085-2089.

Renuka, D.M., Sadashiva, A.T., Kavita, B.T., Vijendrakumar, R.C. and Hanumanthiah, M.R. 2014. Evaluation of cherry tomato lines (Solanum lycopersicum var. cerasiforme) for growth, yield and quality traits. Plant Archives. 14: 151154.

Rodríguez, A., Prohens, J., Solbes, E., Fernández, P. and Nuez, F. 2003. Characterization of North American heirloom tomatoes. Report of the Tomato Genetics Cooperative. 53: 28.

Rosales, M.A., Cervilla, L., Sanchez-Rodriguez, E., Rubio-Wilhelmi, M. and Blasco, B. 2011. The effect of environmental conditions on nutritional quality of cherry tomato fruits: Evaluation of two experimental Mediterranean greenhouses. Journal of the Science of Food and Agriculture. 9: 152-162. 
Sanchez, F.B., Ribeiro, L.P., Rodriues, E.V., Bhering, L.L. and Teodoro, P.E. 2018. Correlation and path analysis of cherry tomato genotypes. Functional Plant Breeding Journal. 1: 1-7.

Sari, B.G., Lucio, A.D., Santana, C.C. and Lopes, S.J. 2017. Linear relationships between cherry tomato traits. Ciencia Rural. 47: 1-7.

Sivasubramanian, S. and Menon, M. 1973. Heterosis and inbreeding depression in rice. Madras Agricultural Journal. 60: 1139-1140.

Stevens, M.A., Kader, A.A., Albright-Holton, M. and Algazi, M. 1977. Genotypic variation for flavor and composition in fresh market tomatoes. Journal of the American Society for Horticultural Science. 102: 680-689.

Stommel, J.R., Abbott, J.A. and Saftner, R.A. 2005. USDA 02L 1058 and 02L1059: Cherry tomato breeding lines with high fruit $\beta$-carotene content. HortScience. 40: 1569-1570.

Testa, R., di Trapani, A., Sgroi, F. and Tudisca, S. 2014. Economic sustainability of Italian greenhouse cherry tomato.
Sustainability 6: 7967-7981.

Thamburaj, S. 1998. Breeding for high quality vegetable, In: National Symposium on Emerging Scenario in Vegetable Research and Development (ed. G. Kalloo), 12-14 Dec. 1998, Indian Institute of Vegetable Research, Varanasi, India, pp. 53-59.

Venkadeswaran, E., Irene, Vethamoni P., Arumugam, T., Manivannan, N. and Harish, S. 2018. Evaluating the yield and quality characters of cherry tomato [Solanum lycopersicum (L.) var. cerasiforme Mill.] genotypes. International Journal of Chemical Studies. 6: 858-863.

Vidyadhar, B., Tomar, B.S. and Singh, B. 2014. Effect of truss retention and pruning of berry on seed yield and quality of cherry tomato (Solanum lycopersicum var. cerasiforme) grown under different polyhouse structures. Indian Journal of Agricultural Sciences. 84: 1335-1341.

Ward, J.H. J.r 1963. Hierarchical grouping to optimize an objective function. Journal of the American Statistical Association. 58: 236-244.

\section{How to cite this article:}

Debmala Mukherjee, Praveen Kumar Maurya, Tridip Bhattacharjee, Swadesh Banerjee, Subhrajyoti Chatterjee, Sudipa Mal, Ivi Chakraborty, Soumitra Chatterjee, Sunanda Chakraborty, Anirban Maji and Arup Chattopadhyay. 2020. Assessment of Breeding Potential of Cherry Tomato [Solanum lycopersicum var. Cerasiforme (Dunnal) A. Gray] Grown under Open Field to Identify Desirable Alleles. Int.J.Curr.Microbiol.App.Sci. 9(04): 2152-2171. doi: https://doi.org/10.20546/ijcmas.2020.904.258 